\title{
Novel markers to detect HER2 amplification in Breast cancer
}

\author{
Ms. Shikha Mudgal ${ }^{1}$, Dr. Arnav Kalra ${ }^{2}$, Dr. Bina Ravi ${ }^{3}$, Dr. Shalinee Rao ${ }^{4}$, Dr. Nilotpal \\ Chowdhury $^{4}$
}

${ }^{1}$ Ph.D. Scholar, All India Institute of Medical Sciences, Rishikesh,

${ }^{2}$ Department of Medicine, All India Institute of Medical Sciences, Rishikesh

${ }^{3 .}$ Integrated Breast Care Centre, All India Institute of Medical Sciences, Rishikesh

4. Department of Pathology, All India Institute of Medical Sciences, Rishikesh

\section{Corresponding author: \\ Dr. Nilotpal Chowdhury, \\ Department of Pathology,}

All India Institute of Medical Sciences, Rishikesh,

PIN-249203,

India

E-mail: nilotpal.path@aiimsrishikesh.edu.in

Phone: 8475000264

\section{Funding: Self-funded}




\section{Abstract}

Overexpression of HER2 in breast cancer is an important prognostic and predictive biomarker, assessed using immunohistochemistry (IHC) and in situ hybridization (ISH). More than $20 \%$ of tumours are graded equivocal on IHC and is send for reflex testing via ISH. In situ hybridization (ISH) is an expensive assay and is not available widely in resource limiting areas. Therefore, we propose that genes found significantly co-expressed with HER2 in breast cancer can be used as surrogate markers for HER2 in breast cancer which can detect HER2 positivity on IHC itself. This hypothesis is based on analysis of publicly available datasets from the Gene Expression Omnibus (GEO) database. The genes found most significantly correlated with HER2 expression were PGAP3 $(r=0.85)$, GRB7 $(r=0.82)$, STARD3 $(r=0.78)$, CDK12 $(r=0.68)$, PSMD3 $(r=0.67)$ and GSDMB $(r=0.63)$. We hypothesize that these identified surrogate markers for HER2 amplification which can be detected on IHC can detect HER2 amplification status in HER2 equivocal tumors based on IHC staining alone and will reduce the number of HER2 2+ (equivocal) category tumours. 


\section{$\underline{\text { INTRODUCTION }}$}

Human epidermal growth factor receptor- 2 (HER2) is amplified in around 20 to $25 \%$ of breast cancers.[1]. This amplification is associated with an aggressive phenotype with poor prognosis, but which is also amenable to treatment by anti-HER2 treatment [2]. HER2 assessment is a key to personalized treatment, especially with HER2 targeted antibody trastuzumab or pertuzumab, [3] but the treatment options are limited by high financial load.[4] Hence, accurate estimation of IHC status is essential.

The recommended protocol for estimation of HER2 status in breast cancer includes Immunohistochemistry (IHC) as an initial step, followed up, if needed by Fluorescent (or Chromogenic) in-situ hybridization (ISH). Tumour blocks are usually tested first by IHC and graded as $0,+1,+2$ and +3 . Scores 0 and +1 are considered negative whereas +3 is considered positive. Tumors having IHC $2+$ scores are considered tumors of equivocal HER2 amplification status, and which have to be tested again by single or dual probe in situ hybridization (ISH) assay for assessment of the HER2 status [5]. While ISH are considered the "Gold-standard", they are costly and not available widely in many resource poor settings due to the high costs and lack of technical expertise. In this setting, it makes sense economically to examine other surrogate markers of HER2 amplification which have potential to reduce the number of equivocal cases on IHC, which are cheaper and require 
lesser technical expertise. Here, we suggest a set of novel IHC markers which may be used to predict the HER2 status of breast cancer. We start with a description of the method analysis conducted to come to our hypothesis, followed by the results, which will lead to the hypothesis and implications.

\section{METHODS}

NCBI- GEO (Gene Expression Omnibus) database was searched for HER2 positive breast cancer gene expression series in Homo sapiens. We found three datasets for breast cancer patients who had not undergone any systematic therapy,( GSE11121 [6], GSE2034 [7] and GSE7390 [8]). The Clinical characteristics of the patients in the data series are given in Table

1. The raw data (.CEL files)of these three datasets were downloaded from NCBI- GEO database. These file were then normalized using frozen robust multi-array average (fRMA) [9] Bioconductor package in $\mathrm{R}$ version 3.6.6. Probes of the normalized files were collapsed to gene symbols using WGCNA Bioconductor package. Pearson correlation coefficient for each gene in the matrix of all the data sets GSE11121, GSE2034 and GSE7390 were calculated with HER2 gene (ERBB2), using in the statistical environment $\mathrm{R} v$ 3.6.6.

\section{$\underline{\text { RESULTS }}$}

Top most correlated genes with a correlation coefficient above 0.6 were extracted from the combined dataset (Table 2). These genes were PGAP3,GRB7, STARD3, CDK12, PSMD3 and GSDMB All these genes were found to be localized to an area near the locus of HER2 in chromosome 17.

The scatterplot of the expression of the three top genes with HER2 is given in Figure 1. 


\section{DISCUSSION}

We hypothesise that IHC of the obtained HER2 co-amplified proteins (including PGAP3, GRB7, STARD3, CDK12, PSMD3 and GSDMB ) will result in better discrimination of HER2 amplified breast cancer patients from HER2 non-amplified breast cancer patients. Breast cancer sections showing high expression of these markers with strong intensity signal should discriminate between HER2 amplified and HER2 non-amplified cancers in tumors having equivocal HER2 immunostaining. Increased strong intensity signals of two or more such markers should result in greater specificity in detecting HER2 amplified tumors in such equivocal cases. Therefore, IHC of these HER2 co-amplified proteins on breast cancer should result in reduced number of cases needing ISH due to the better discriminatory ability. Since the cost of IHC is significantly lesser than ISH both in terms of reagents as well as equipments and manpower, this may result in greater cost-effectiveness of HER2 assessment. This should enable significant cost-savings in resource-limited settings.

The reasoning behind the above hypotheses is that the genes adjacent to HER 2 on chromosome 17 also get amplified in HER2 amplified tumors. Genomic studies have characterized such "amplicons". Besides predicting HER2 status, these genes may themselves be play an important role in the natural history of breast cancer.

The hypothesis can be confirmed by doing a diagnostic validation study comparing the IHC biomarkers of the gene products of the HER2 co-expressed genes with HER2. A significant subset of this validation study should be consist of HER2 equivocal (2+) cases. The equivocal cases should be confirmed by in-situ hybridization. If the expression of the IHC positivity of the top HER2 co-expressed genes significantly predicts the HER2 status in IHC equivocal cases of HER2, and if found to be significantly correlated with the IHC staining pattern of HER2, the hypothesis will be deemed to be supported by evidence to put in regular diagnostic 
medRxiv preprint doi: https://doi.org/10.1101/2021.11.20.21266647; this version posted November 23, 2021. The copyright holder for this preprint (which was not certified by peer review) is the author/funder, who has granted medRxiv a license to display the preprint in perpetuity. It is made available under a CC-BY-NC 4.0 International license.

use. A further implication of the hypothesis will be that a reference probe targeting these proteins should also result in a good alternative chromosome 17 reference probe for cases found equivocal even after In-situ hybridization for HER2.

Conflicts of interest: The authors declare no conflicts of interest 


\section{REFERENCES}

1. Liu Y, Wu S, Shi X, Luo Y, Pang J, Wang C, et al. HER2 double-equivocal breast cancer in Chinese patients: a high concordance of HER2 status between different blocks from the same tumor. Breast Cancer Res Treat [Internet]. 2019; Available from: https://doi.org/10.1007/s10549-019-05387-6

2. Ivkovic-Kapic T, Knezevic-Usaj S, Moldvaji E, Jovanic I, Milovanovic Z, Milentijevic M, et al. Interlaboratory concordance in HER2 testing: Results of a Serbian ring-study. J BUON. 2019;24(3):1045-53.

3. Gingras I, Gebhart G, De Azambuja E, Piccart-Gebhart M. HER2-positive breast cancer is lost in translation: Time for patient-centered research. Nat Rev Clin Oncol [Internet]. 2017;14(11):669-81. Available from: http://dx.doi.org/10.1038/nrclinonc.2017.96

4. Solomon JP, Dell'Aquila M, Fadare O, Hasteh F. Her2/neu Status Determination in Breast Cancer. Am J Clin Pathol. 2017;147(4):432-7.

5. Wolff AC, Hammond MEH, Allison KH, Harvey BE, Mangu PB, Bartlett JMS, et al. Human Epidermal Growth Factor Receptor 2 Testing in Breast Cancer. 2018;2.

6. Dieci MV, Barbieri E, Bettelli S, Piacentini F, Omarini C, Ficarra G, et al. Predictors of human epidermal growth factor receptor 2 fluorescence in-situ hybridisation amplification in immunohistochemistry score 2+ infiltrating breast cancer: A single institution analysis. J Clin Pathol. 2012;65(6):503-6.

7. Payandeh M, Sadeghi M, Sadeghi E, Kabir koohian A. Comparison of IHC, FISH, ER and PR in Breast Cancer in Western Iran. Am J Cancer Prev. 2014;2(2):37-41.

8. Musa ZA, Qasim BJ, Al Shaikhly AWAK. Evaluation of immunohistochemistryequivocal (2+) HER2 gene status in invasive breast cancer by silver DNA in situ 
hybridization (SISH) and its association with clinicopathological variables. Iran J Pathol. 2017;12(1):9-19.

9. Panjwani P, Epari S, Karpate A, Shirsat H, Rajsekharan P, Basak R, et al. Assessment of HER-2/neu status in breast cancer using fluorescence in situ hybridization \& immunohistochemistry: Experience of a tertiary cancer referral centre in India. Indian $\mathbf{J}$ Med Res. 2010;132(9):287-94.

10. Solomon JP, Aquila MD, Fadare O, Hasteh F. Her2 / neu Status Determination in Breast Cancer A Single Institutional Experience Using a Dual-Testing Approach With Immunohistochemistry and Fluorescence In Situ Hybridization. 2017;

11. Kenn M, Cacsire Castillo-Tong D, Singer CF, Cibena M, Kölbl H, Schreiner W. Coexpressed genes enhance precision of receptor status identification in breast cancer patients. Breast Cancer Res Treat [Internet]. 2018;172(2):313-26. Available from: http://dx.doi.org/10.1007/s10549-018-4920-x

12. Kenn M, Schlangen K, Castillo-Tong DC, Singer CF, Cibena M, Koelbl H, et al. Gene expression information improves reliability of receptor status in breast cancer patients. Oncotarget. 2017;8(44):77341-59.

13. Pan X, Hu XH, Zhang YH, Chen L, Zhu LC, Wan SB, et al. Identification of the copy number variant biomarkers for breast cancer subtypes. Mol Genet Genomics [Internet]. 2019;294(1):95-110. Available from: http://dx.doi.org/10.1007/s00438-018-1488-4

14. Pradip D, Bouzyk M, Dey N, Leyland-Jones B. Dissecting GRB7-mediated signals for proliferation and migration in HER2 overexpressing breast tumor cells: GTP-ase rules. Am J Cancer Res [Internet]. 2013;3(2):173-95. Available from: http://www.ncbi.nlm.nih.gov/pubmed/23593540\%0Ahttp://www.pubmedcentral.nih.g ov/articlerender.fcgi?artid=PMC3623837

15. Glynn RW, Miller N, Mahon S, Kerin MJ. Expression levels of HER2/neu and those 
of collocated genes at 17q12-21, in breast cancer. Oncol Rep. 2012;28(1):365-9.

16. Saito M, Kato Y, Ito E, Fujimoto J, Ishikawa K, Doi A, et al. Expression screening of 17q12-21 amplicon reveals GRB7 as an ERBB2-dependent oncogene. FEBS Lett [Internet]. 2012;586(12):1708-14. Available from:

http://dx.doi.org/10.1016/j.febslet.2012.05.003

17. Luoh S, Wagoner W, Wang X, Hu Z, Lai X, Chin K. U . S . Department of Veterans Affairs. 2019;58(5):699-707.

18. Bivin WW, Yergiyev O, Bunker ML, Silverman JF, Krishnamurti U. GRB7 Expression and Correlation with HER2 Amplification in Invasive Breast Carcinoma. Appl Immunohistochem Mol Morphol. 2017;25(8):553-8.

19. Hongisto V, Aure MR, Mäkelä R, Sahlberg KK. The HER2 amplicon includes several genes required for the growth and survival of HER2 positive breast cancer cells - A data description. Genomics Data. 2014;2:249-53.

20. elevated level of STARD3 alter cholesterol balance and adhesieness of BC.pdf.

21. quntification and clinical relevance.pdf.

22. unraveling the chr 17 patterns of FISH in interphase nuclei.pdf.

23. Naidoo K, Wai PT, Maguire SL, Daley F, Haider S, Kriplani D, et al. Evaluation of CDK12 protein expression as a potential novel biomarker for DNA damage responsetargeted therapies in breast cancer. Mol Cancer Ther. 2018;17(1):306-15.

24. cdk12 regulates alternative last exon mRNA spicing and promotes BC cell invasion.pdf.

25. psmd3 regulates bc.pdf.

26. her2 amplicon includes several genes.pdf.

27. Gasdermin B expression predicts poor clinical outcome in HER2-positive breast cancer Generation of GSDMB antibody. 
28. gasdermin B promotes invasion and metastasis in BC cells.pdf.

29. Molina-Crespo Á, Cadete A, Sarrio D, Gámez-Chiachio M, Martinez L, Chao K, et al. Intracellular Delivery of an Antibody Targeting Gasdermin-B Reduces HER2 Breast Cancer Aggressiveness. Clin Cancer Res. 2019;25(15):4846-58.

30. High Resolution Genomic Analysis of 18q-.pdf.

31. Schmidt M, Böhm D, Von Törne C, Steiner E, Puhl A, Pilch H, et al. The humoral immune system has a key prognostic impact in node-negative breast cancer. Cancer Res. 2008;68(13):5405-13.

32. Wang Y, Klijn JGM, Zhang Y, Sieuwerts AM, Look MP, Yang F, et al. Geneexpression profiles to predict distant metastasis of lymph-node-negative primary breast cancer. Lancet. 2005;365(9460):671-9.

33. Desmedt C, Piette F, Loi S, Wang Y, Lallemand F, Haibe-Kains B, et al. Strong time dependence of the 76-gene prognostic signature for node-negative breast cancer patients in the TRANSBIG multicenter independent validation series. Clin Cancer Res. 2007;13(11):3207-14.

34. McCall MN, Bolstad BM, Irizarry RA. Frozen robust multiarray analysis (fRMA). Biostatistics. 2010;11(2):242-53. 


\section{$\underline{\text { TABLES }}$}

Table 1 . Summary of patient's characteristics of the three series analysed.

\begin{tabular}{|c|c|c|c|}
\hline & GSE2034(N=286) & GSE11121( $\mathrm{N}=200)$ & GSE7390 $(\mathrm{N}=198)$ \\
\hline $\begin{array}{l}\text { Median follow up period in years. } \\
\text { (range) }\end{array}$ & $8.8(0.17-14.25)$ & $8.6(0.08-20.00)$ & $13.7(0.34-24.95)$ \\
\hline Mean patient age in years (range) & $54(26-83)$ & $60(25-90)$ & $46(24-60)$ \\
\hline \multirow[t]{3}{*}{ Radiotherapy given } & 248 & 125 & - \\
\hline & 38 & 75 & - \\
\hline & 00 & 00 & 198 \\
\hline
\end{tabular}

Table 2: The location of the top genes correlated with HER2.

\begin{tabular}{|c|c|c|c|c|}
\hline Genes & $\begin{array}{l}\text { Correlation } \\
\text { coefficient }\end{array}$ & Protein & Subcellular location & $\begin{array}{l}\text { Chromosome location on } \\
\text { GRCh38 reference genome }\end{array}$ \\
\hline ERBB2 & - & HER2 & Cell membrane & $\begin{array}{l}17 q 12 \\
(39688084 . .39728662)\end{array}$ \\
\hline PGAP3 & 0.85 & $\begin{array}{l}\text { Post-GPI attachment to } \\
\text { proteins factor } 3\end{array}$ & $\begin{array}{l}\text { Endoplasmic reticulum } \\
\text { membrane, Golgi apparatus } \\
\text { membrane }\end{array}$ & $\begin{array}{l}17 q 12 \\
(39671122 . .39688070)\end{array}$ \\
\hline GRB7 & 0.82 & $\begin{array}{l}\text { Growth factor receptor- } \\
\text { bound protein } 7\end{array}$ & Plasma membrane & $\begin{array}{l}17 q 12 \\
(39737938 . .39747285)\end{array}$ \\
\hline STARD3 & 0.78 & $\begin{array}{l}\text { StAR-related lipid } \\
\text { transfer protein } 3\end{array}$ & Late endosome membrane & $\begin{array}{l}17 q 12 \\
(39637080 . .39664201)\end{array}$ \\
\hline CDK12 & 0.68 & $\begin{array}{l}\text { Cyclin dependent } \\
\text { kinase } 12\end{array}$ & $\begin{array}{l}\text { Nucleus } \\
\text { Nucleus speckle }\end{array}$ & $\begin{array}{l}17 q 12 \\
(39461486 . .39567560)\end{array}$ \\
\hline PSMD3 & 0.67 & $\begin{array}{l}\text { 26S Proteasome non- } \\
\text { ATPase regulatory } \\
\text { subunit } 3\end{array}$ & $\begin{array}{l}\text { Cytosol, nucleosome, } \\
\text { nucleus }\end{array}$ & $17 \mathrm{q} 21.1$ \\
\hline
\end{tabular}


medRxiv preprint doi: https://doi.org/10.1101/2021.11.20.21266647; this version posted November 23, 2021. The copyright holder for this preprint (which was not certified by peer review) is the author/funder, who has granted medRxiv a license to display the preprint in perpetuity.

It is made available under a CC-BY-NC 4.0 International license .

\begin{tabular}{llll}
\hline GSDMB & $0.63 \quad$ Gasdermin - B & Cytosol, Cell membrane & (39980807..39997959)
\end{tabular}

\section{FIGURE LEGENDS}

Figure 1: Scatter plot showing correlation of PGAP3, GRB7 and STARD3 genes with

ERBB2 genes in GSE11121, GSE2034 and GSE7390 datasets.
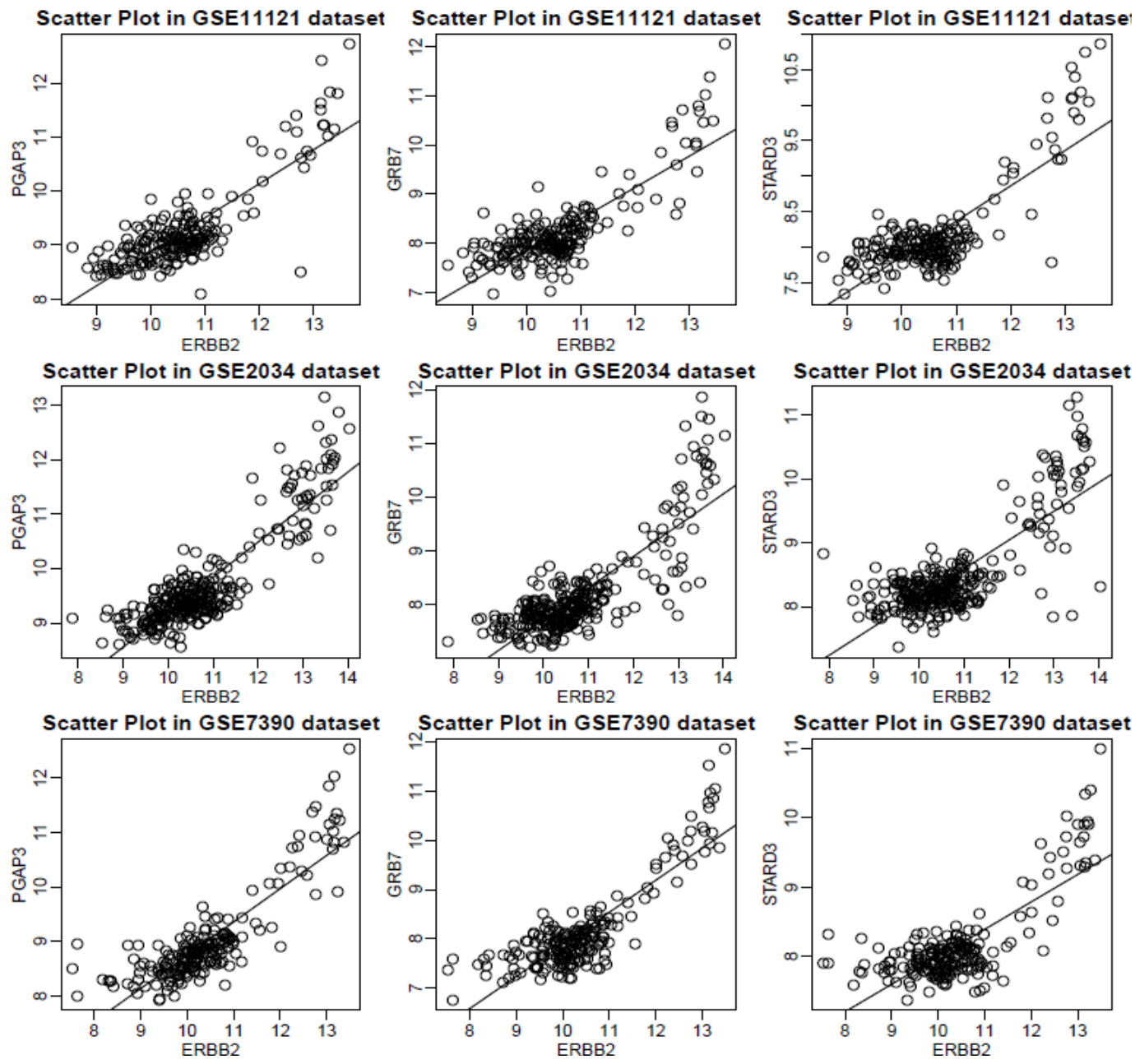